Tyndale Bulletin 71.1 (2020) 65-73

\title{
ON SOME ALLEGED ANACHRONISMS IN THE BOOKS OF SAMUEL
}

\author{
Alan Millard \\ (amillard@liv.ac.uk)
}

\begin{abstract}
Summary
In considering the age and historical reliability of the Books of Samuel, the detection of anachronisms can play a major part. A number that have been alleged are examined in this essay, and no good grounds are found for accepting them.
\end{abstract}

\section{Introduction}

To assert the presence of an anachronism in a text claiming to describe a particular moment in the past is to create an aura of doubt which is hard to disperse. So many commentators have identified anachronisms in biblical texts that biblical narratives are frequently believed to be unhistorical, following the adage 'Give a dog a bad name ...' This is easy to do, but to disprove an anachronism is often more difficult. Yet every ancient text deserves to be treated with respect, its witness only doubted when evidence is unexceptionable - anachronisms should be proved.

In a book published in 1992 the eminent Egyptologist Donald Redford argued that the books of Samuel cannot be treated as trustworthy historical sources. He asserted:

Blatant anachronisms are more numerous than a record with reliable sources should contain: coined money (1 Sam. 13:21), late armor (1 Sam. 17:4-7, 38-39; 25:13), the use of camels (1 Sam. 30:17) and cavalry (distinct from chariotry: $1 \mathrm{Sam} .13: 5 ; 2$ Sam. 1:6), iron picks and axes (as though they were common: 2 Sam. 12:31), and sophisticated siege techniques (2 Sam. 20:15). 
He also mentions this in the so-called 'Succession Document' 'The author has his characters wear archaic clothing (2 Sam. 13:18), talk of coined money (2 Sam. 18:11-12) ...'1 Students have accepted these statements without examination, but some are misleading and some are wrong.

I have contested Redford's assertions about coined money, late armour and 'sophisticated siege techniques' in previous studies. ${ }^{2}$ This essay offers responses to the remaining topics.

\section{The Use of Camels}

And David smote them [the Amalekites] from twilight until the evening of the next day; and not a man of them escaped, except four hundred young men, who mounted camels and fled. (1 Sam. 30:17)

For decades biblical scholars have followed the repeated assertion of W. F. Albright that camels were not domesticated in the Near East before the eleventh century BC. ${ }^{3}$ It is that assumption, presumably, which lies behind the assertion that camels in this passage is anachronistic, even though it is set near the end of the eleventh century.

All are now agreed that the camel became a means of transport across the Near East from the twelfth century BC onwards. The Assyrian king Ashur-bel-kala (c. 1074-1057 BC) boasts of his merchants acquiring camels, which he then bred and put on show with other foreign creatures. ${ }^{4}$ The camel was not suited to urban or riverine environments, being at home in the steppe or desert. Thus the paucity

1 Donald B. Redford, Egypt, Canaan and Israel in Ancient Times (Princeton: Princeton University Press, 1992): 305.

2 'The Armor of Goliath' in Exploring the Longue Durée: Essays in Honor of Lawrence E. Stager, ed. David Schloen (Winona Lake: Eisenbrauns, 2008): 337-43; 'Are there Anachronisms in the Books of Samuel?' in Studies on the Text and Versions of the Hebrew Bible in Honour of Robert Gordon, ed. Geoffrey Khan and Diana Lipton (Vetus Testamentum Supp. 149; Leiden: Brill, 2011): 39-48.

3 William F. Albright, Archaeology and the Religion of Israel (Baltimore: Johns Hopkins Press, 1942): 96, 132f; History, Archaeology and Christian Humanism (New York: McGraw-Hill, 1964): 158 n.2.

4 A. Kirk Grayson, Royal Inscriptions of Mesopotamia, Assyrian Period, Assyrian Rulers of the Early First Millennium BC, 1 (1114-859 BC) (Toronto: University Press, 1991): 103-104, lines 25-28, cf. 98, lines 2', 3'. On camels in the ancient Near East, see the extensive discussion by Martin Heide, 'The Domestication of the Camel', Ugarit Forschung 42 (2010): 331-82, with much detail, full references, and discussion of camels in the Middle Bronze Age and before it. 
of references to camels in the Bible as in other ancient documents is largely due to the nature of those documents, almost all of them being produced in towns for the inhabitants of towns. However, the range of written references and artistic representations show the camel was known and used across the Fertile Crescent from the Late Bronze Age onwards. Sites on the desert edges of eastern Arabia have, not surprisingly, yielded camel bones in large quantities from the third and second millennia BC. Therefore, the mention of camels in the biblical text dealing with late eleventh-century raiders, the Amalekites, from the steppe where camels were at home presents no difficulty. ${ }^{5}$

\section{Cavalry (Distinct from Chariotry)}

And the Philistines mustered to fight with Israel, thirty thousand chariots, and six thousand horsemen, and troops like the sand on the seashore in multitude. (1 Sam. 13:5)

And the young man who told him said, 'By chance I happened to be on Mount Gilbo'a; and there was Saul leaning upon his spear; and lo, the chariots and the horsemen were close upon him.' (2 Sam. 1:6)

The earliest Assyrian king to tell of his cavalry, but without any suggestion that it was an innovation, was Tukulti-Ninurta II (890-884 $\mathrm{BC}$ ), who found the terrain in the Kurdish hills east of the Tigris so difficult that 'one could cross neither with my chariots nor with cavalry' (pithalli). ${ }^{6}$ Earlier than that, in the Late Bronze Age, cavalrymen figure in some administrative and royal records from Assyria and Babylonia as well as in a Hittite royal letter.

The Hebrew word translated 'cavalry' ( $p \bar{a} r \bar{a} s h)$ is defined as 'horse, horsemen' in the Dictionary of Classical Hebrew, in line with other dictionaries, with entries 1. 'horse', 2. 'horsemen, usu[ally] not as rider but as charioteer (unless all are 1.)'. ${ }^{7}$ This range of meaning is comparable with the range of meaning given for the Akkadian pethallu, 1. 'equid, riding animal, 2. (a) cavalry (as collective) (b) personnel

5 See Juris Zarins, 'Camel' in The Anchor Bible Dictionary I, ed. David N. Freedman et al. (New York: Doubleday, 1992): 824-26.

6 Grayson, Royal Inscriptions, 173.

7 Dictionary of Classical Hebrew 6, ed. David J. A. Clines, et al. (Sheffield: Phoenix Press, 2007): 787. 
connected with cavalry' and $\check{s} a$ pethallu, 'cavalryman'. ${ }^{8}$ The Akkadian means literally 'open thighs', so it may be equated with the Hebrew pārāsh if that can be taken as a bi-form of pārāś, 'to spread (legs)', as David Ap-Thomas suggested in $1970 .{ }^{9}$ Since the two passages in Samuel are alleged to refer anachronistically to cavalry, the possibility of cavalry in David's time is examined here (while noting that it may not have that meaning, as argued by Deborah Cantrell). ${ }^{10}$

Rendering the term 'cavalry' may import a more regimented concept than one or many 'horsemen', as Alan Schulman observed, quoted by Ap-Thomas:

It can be argued that, since riding was done on a relatively small scale, to call the riders cavalry is inappropriate. Yet they fulfilled one of the main functions of cavalry, that of providing reconnaissance and intelligence, and for that reason surely deserve to be called cavalry. ${ }^{11}$

Schulman noted that carvings of the Battle of Qadesh include Egyptian mounted scouts and a few Hittites and Syrians riding horses. ${ }^{12}$ However, Ap-Thomas preferred to be more precise. For him, cavalry meant 'massed formations of horse-riding combat troops', which, he claimed, 'almost certainly came into use in the Fertile Crescent first in the Assyrian army of Asshurnasirpal (884-860 BC)', an assertion recently repeated by Deborah Cantrell. ${ }^{13}$ Curiously, in 1937, Kurt Galling dated that innovation later: "the Assyrians in the eighth century were the first to form massed cavalry detachments'. ${ }^{14}$ Neither author was aware of the word's earliest occurrence in an Assyrian royal inscription of Ashurnasirpal's father, Tukulti-Ninurta II (890-884 BC), first published in 1909, as noted above. No text hails the introduction of horsemen into the Assyrian army; they do not appear in the

8 The Assyrian Dictionary 12, P (Chicago: The Oriental Institute, 2005): 335-37.

9 David Ap-Thomas, "“All the King's Horses”: A Study of the Term פרש (I Kings 5. 6 [EVV., 4.26] etc.)' in Proclamation and Presence: Old Testament Essays in Honour of Gwynne Henton Davies, ed. John I. Durham and J. Roy Porter (London: SCM Press, 1970): 135-51, see 149.

10 Deborah O'D. Cantrell, The Horsemen of Israel: Horses and Chariotry in Monarchic Israel (Ninth-Eighth Centuries B.C.E.) (Winona Lake, IN: Eisenbrauns, 2011).

11 Ap-Thomas, “"All the King's Horses"”, 143.

12 Alan R. Schulman, 'Egyptian Representations of Horsemen and Riding in the New Kingdom', JNES 16 (1957): 263-71.

13 Cantrell, The Horsemen of Israel, 136.

14 Biblisches Reallexikon (Tubingen: J. C. B. Mohr, 1937): 420, cited by Ap-Thomas, 144. 
campaign accounts of Tiglath-pileser I (c. 1114-1076 BC). There was a period of weakness from the middle of the eleventh century, with no records of major campaigns until the reign of Ashur-dan II (934-912 $\mathrm{BC}$ ), whose 'annals' report a resurgence of military activity. That could have included the incorporation of horsemen, although none are mentioned.

Those Assyrian royal inscriptions of the ninth century are not the first cuneiform texts in which horsemen appear. A decree of Nebuchadnezzar I (c. 1124-1103 BC) rules that no horseman should levy riding horses from certain towns, and a letter from the Hittite queen Puduhepa in the thirteenth century uses the Akkadian word LÚpit.hal.li, where presumably the reader was expected to speak a Hittite one. A thirteenth-century administrative tablet, perhaps from north-west Mesopotamia, mentions a horseman in some official capacity. ${ }^{15}$ On a cylinder seal of the same date from Ugarit is engraved a rider on a horse, which was, presumably, a picture of some significance. Horses were valued at Ugarit, being mentioned in ones or twos in letters and accounts, but two documents each report two thousand horses. They are often linked with chariots, yet some were ridden, as the seal shows. ${ }^{16}$

The Egyptian documents studied by Schulman portray horsemen in military contexts. He noted depictions of the Canaanite goddess Astarte on horseback and they were given a full study shortly afterwards by Jean Leclant. ${ }^{17}$ Egyptian representations of Astarte show her riding a horse and either brandishing a spear or shooting with a bow and arrow. One sculpture is a monument of Seti I (c. 1294-1279 BC) and mounted scouts were active in the Battle of Qadesh of c. 1274, as already noted. The variety of these depictions of Astarte in the New Kingdom (c. 1550-1069 BC) shows that the figure of the goddess riding a horse and brandishing weapons was well known. Since Astarte was imported from the Levant, it is reasonable to suppose that her iconography

15 Leonard W. King, Babylonian Boundary-Stones and Memorial Tablets in the British Museum (London: The British Museum, 1912): 33, lines 58-59; Harry A. Hoffner, Letters from the Hittite Kingdom (Writings from the Ancient World 15; Atlanta, GA: SBL, 2009): 283-84, lines 18', 24'; J. Nicholas Postgate, 'Middle Assyrian Texts 9 Nos 99-101' in Cuneiform Texts in the Metropolitan Museum of Art 1, ed. Ira Spar (New York: Metropolitan Museum, 1988): no. 99.

16 Florence Malbran-Labat and Carole Roche, 'Les Chevaux en Ougarit: Élevage et Commerce', Études Ougaritiques 2, Ras Shamra-Ougarit 20 (2012): 275-81.

17 Jean Leclant, 'Astarte à cheval', Syria 37 (1960): 1-67. 
accompanied her, although no similar representations of her have been identified in her homeland. More recently, a relief was discovered at Tell el-Borg in western Sinai, which shows Astarte enthroned upon a horse. ${ }^{18}$ Here she finds company in Babylonian seals engraved with enthroned deities seated on animals, one apparently a horse, but none are Astarte, and enthronement is rather different from riding!

\section{Iron Picks and Axes}

And he brought forth the people who were in it [Rabbath Ammon], and set them to labour with saws and iron picks and iron axes. (2 Sam. $12: 31)$

These tools are mentioned 'as though they were common', asserted Redford. Here the interpretation made may be contested. Why should the material of the tools be mentioned if it was common? We may treat the qualification 'iron', rather, as a sign of something unusual, the use of the harder metal, maybe less common at the time, indicating the severity of the punishment.

The way the Philistines restricted the Israelites by requiring them to take their tools to Philistine smiths for repair also indicates a limited availability of the necessary skills (1 Sam. 13:21). The charge of payim made for sharpening ploughshares and mattocks was elucidated by the discovery over a century ago of small stone weights marked in early Hebrew script pym. Their weight proves pym means 'two thirds [of a shekel]'. The fact that the pym weights only occur from the late eighth century onwards does not mean 1 Samuel 13:21 contains an anachronism, as Anthony Frendo assumed, for that would mean a unit of weight could not exist earlier than the marked stones, although countless unmarked stone weights survive from previous centuries at many sites! 19

18 James K. Hoffmeier and Kenneth A. Kitchen, 'Resheph and Astarte in North Sinai: A Recently Discovered Stela from Tell el-Borg', Ägypten und Levante 17 (2007): 127 36.

19 Anthony J. Frendo, Pre-Exilic Israel, The Hebrew Bible, and Archaeology: Integrating Text and Artefact (Library of Hebrew Bible/Old Testament Studies 349; London: T \& T Clark, 2011): 71. For the marked weights, see Raz Kletter, Economic Keystones: The Weight System of the Kingdom of Judah (Sheffield: Sheffield Academic Press, 1998). 
The qualification of Canaanite chariots as 'iron' can also be understood as signaling an unusual element in their structure at a time when the material was still rare. ${ }^{20}$ From excavations across the Holy Land, it is clear that iron tools and weapons were beginning to be used in Iron Age I, becoming more common in Iron Age II. The site of Khirbet Qeiyafa, which belongs to the early phase of Iron Age II, yielded a number of iron tools and weapons, beside bronze ones. ${ }^{21}$

\section{Archaic clothing}

Now she was wearing a long robe with sleeves; for thus were the virgin daughters of the king clad of old. (2 Sam. 13:18)

Another 'clear indication of a date long after the events described' is seen in the way the 'author has his characters wear archaic clothing (2 Sam. 13:18)'. This 'clear indication', which refers to only a particular group of people, is actually a conjecture by nineteenth-century biblical scholars. The Hebrew text has

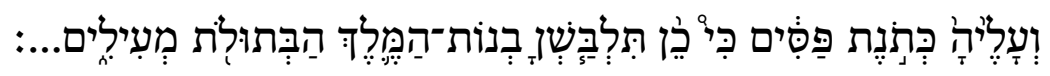

which the AV renders 'And she had a garment of divers colours upon her: for with such robes were the king's daughters that were virgins apparelled.'

The word translated 'robes' (Heb. me'îlim) S. R. Driver said is awkward here, as duplicating the term 'garment', on the assumption

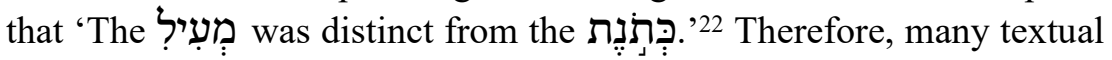
critics have preferred to repoint the consonantal text to read mé'ôlamm, 'from of old'. (The letters $m$ ' $m$ allow either reading.) Several English versions have adopted this conjecture. The RSV has 'Now she was

20 See A. R. Millard, 'King Og's Bed and Other Ancient Ironmongery' in Ascribe to the Lord: Biblical and Other Studies in Memory of Peter C. Craigie, ed. Lyle Eslinger and Glen Taylor (Sheffield: Sheffield Academic Press, 1988): 481-92; 'Back to the Iron Bed: Og's or Procrustes'?' in Congress Volume, Paris 1992, Vetus Testamentum Supplement 61, ed. John A. Emerton (Brill: Leiden, 1995): 193-203.

21 Yulia Gottlieb, 'The Advent of the Age of Iron in the Land of Israel: A Review and Reassessment', Tel Aviv 37 (2010): 89-110; Yosef Garfinkel, 'The Iron Age City of Khirbet Qeiyafa' in The Shephelah during the Iron Age: Recent Archaeological Studies, ed. Oded Lipschitz and Aren M. Maeir (Winona Lake, IN: Eisenbrauns, 2017): 115-31, see 124-25.

22 Samuel R. Driver, Notes on the Hebrew Text and the Topography of the Books of Samuel (2nd ed.; Oxford: Clarendon Press, 1913): 299-300. 
wearing a long robe with sleeves; for thus were the virgin daughters of the king clad of old' with a footnote 'Heb. clad in robes'. The NRSV follows with 'Now she was wearing a long robe with sleeves; for this is how the virgin daughters of the king were clothed in earlier times' with a footnote 'Cn: Heb were clothed in robes'. The New Jerusalem Bible is similar: 'She was wearing a magnificent dress, for this was what the king's unmarried daughters wore in days gone by.' The Good News Translation adopts the same rendering - 'Tamar was wearing a long robe with full sleeves, the usual clothing for an unmarried princess in those days' - with the footnote 'Probable text in those days; Hebrew garments'. The New Living Translation also has 'She was wearing a long, beautiful robe, as was the custom in those days for the king's virgin daughters' without a footnote. On the other hand, the Revised Version follows the Authorised Version: 'she had a garment of diverse colours upon her; for with such robes were the king's daughters that were virgins apparelled'. The NIV and ESV follow suit.

Yet there is no need to repoint the text, for the assumption that 'robes' duplicates 'garment' misunderstands the intent of the Hebrew, which is to explain that the girls wore a special dress as their robe. The emendation seems unnecessary and cannot be the basis for a charge of anachronism against the author of this text.

Tamar's special dress may appear 'archaic' because the only other person to wear one was the patriarch Joseph, whose garment has passed into popular tradition as 'a coat of many colours', as seen in the famous Egyptian Beni Hasan tomb painting, although 'a garment with long sleeves' is usually considered more likely (Gen. 37:3,23,32). That does not make it 'archaic' in Samuel, only 'rare', especially as most scholars place the composition of Genesis in the first millennium. It is worth noting that the word occurs outside Hebrew. A list of garments found at Ugarit, written in the local cuneiform alphabet, includes a 'fine' (or 'light') 'psm garment' (lbš psm zq). ${ }^{23}$ There can be no doubt Ugaritic psm is the same term as Hebrew passim, whatever its precise meaning. The Babylonian pussumu, 'veil', and related verb pasāmu, 'to cover,

23 Charles Virolleaud, Le Palais royal d'Ugarit II (Paris: Imprimerie Nationale, 1957): 146; KTU 4.205.5; André Caquot, Les Livres de Samuel (Commentaire de l'Ancien Testament VI, Geneva: Labor et Fides, 1994): 498-99; Gregorio del Olmo Lete, Joaquín Sanmartín, and Wilfred G. E. Watson, A Dictionary of the Ugaritic Language in the Alphabetic Tradition (Handbook of Oriental Studies, Section 1, the Near and Middle East, 112, 3rd ed.; Leiden: Brill, 2015). 
hide', present in texts from the early second and first millennia, provide instructive cognates. ${ }^{24}$ There is no reason to treat the word as an archaism in the biblical texts. ${ }^{25}$

\section{Conclusion}

After examining them, none of the alleged anachronisms appear to be well founded. Some cases are clearly not anachronistic (camels, iron tools, 'archaic' clothing); each could be at home in Israel in the eleventh century BC. For cavalry, the evidence is weaker, while still sufficient to refute the allegation. Whoever the ancient scholars who compiled the Books of Samuel were, and whenever they worked, their depiction of the days of David is more accurate than Redford supposed.

24 See The Assyrian Dictionary 12, P (Chicago: The Oriental Institute, 2005).

25 Redford cites Ephraim Spesier's attempt to find a cognate in Babylonian pisannu a term for a piece of clothing found in documents from the sixth century $\mathrm{BC}$ and later, which should be discounted in the light of the Ugaritic tablet. Ephraim A. Speiser, Genesis (The Anchor Bible; New York: Doubleday, 1962): 289-90. 